\title{
Urbanization and Mutual Help Groups: Contribution to Nation-Building in Tanzania
}

\section{Oxana Ivanchenko}

Institute for African Studies, Moscow National Research University Higher School of Economics, Moscow

\section{Anastasia Banshchikova}

Institute for African Studies, Moscow National Research University Higher School of Economics, Moscow

\begin{abstract}
The article is devoted to mutual help groups in Dar es Salaam, Tanzania, as an input to the country's successful nation-building process. It summarizes the results of field researches conducted by Oxana $V$. Ivanchenko in 2011, 2013, and 2015. The research targeted the practices of mutual help and self-organization among citizens of one of the most rapidly growing mega-cities in Africa, both its second-and third-generation old-timers and newcomers, usually the poorest Tanzanian villagers who rush to the big city in search for a better life. The methods of research include participant observation and interview, both formal and informal, with the inhabitants of uswahilini, traditional African neighborhoods, most commonly bearing the status of informal settlements. The research is focused on various forms of mutual help groups (kufa na kuzikana, mchezo/upatu, and vikoba), which nowadays tend to transform and carry out same functions of microcrediting, money-saving, loan-giving, providing the insurance in case of emergency (death, illness), and insuring socialization and strengthening of friendly relations in general. Over the course of data analysis, the authors come to a conclusion that the Tanzanians, who moved to the city, recreate the communal way of life of rural areas though in adapted forms: neighbors and colleagues become their new environment that provides social guarantees and help in difficult situation instead of relatives, and the leaders of mutual help groups help
\end{abstract}

Social Evolution \& History, Vol. 17 No. 1, March 2018 34-59

(C) 2018 'Uchitel' Publishing House

DOI: $10.30884 / \mathrm{seh} / 2018.01 .03$ 
resolve conflicts instead of the police. Strong pre-state traditions of community life and self-organization, characteristic of rural Tanzania, nowadays help urban Tanzania to grow up. And, what is even more important is that if earlier these traditions used to function only among same-tribe or same-region Tanzanians and would remain on the ethnic level, later in big cities they would flourish on inter-ethnic and supra-ethnic levels, because the need in mutual help did not disappear, while same-tribe friends and relatives were far away. Thus, it is clear that under peaceful circumstances urbanization and mutual help practices contribute to the nation-building process: people move from village to city and from traditional social bonds (on the level of tribe, region of provenance) to chosen social bonds (on nation-level, because all other ones are already overcome or non-existent).

\section{INTRODUCTION}

Tanzania can be considered as a successful example of postcolonial African state. The socio-cultural base of its stability formed long before colonization: in the nineteenth century the Swahili culture and language spread from coastal areas to inner parts of the country thus becoming the means of interethnic communication and later on, Swahili became the official language of Tanzania. The Swahili culture emerged as a synthesis of local and Arab traditions, brought from Arabian Peninsula in the Middle Ages, and nowadays it is perceived as native and autochthonous by the majority of population regardless of provenance and confession (Bondarenko 2008; Ivanchenko 2013). The challenges of state- and nation-building in post-colonial Tanzania were much less severe and became fully reconciled due to the presence of already formed supra-tribal unity without serious internal conflicts and tensions (Bondarenko 2016: 231).

However, the emergence and existence of a stable nation-state does not mean that stadial and civilizational heterogeneity, inherent in most of post-colonial states, disappear (Ibid. 224). As it is stated in the Introduction to the present volume,

The elements of capitalism, implanted by the Europeans in different spheres, did not synthesize with a set of precapitalist features of the local societies. There also was little intersection between the autochthonous and new sectors of public life, in which basically different value systems dominated (Ibid.: 224).

The formation of the Tanzanian nation, supported by the state's efforts, most intensively proceeds in the urban environment. Moreover, the whole diversity of ethnic groups, confessions, and social classes historically unite in large cities; and a new and peculiar culture, which 
transforms traditional views in many ways and creates new social ideas, is formed there. The study of this urban 'melting pot' directly contributes to the study of nation-building in general: people tend to lose the mentality, way of thinking and prejudice that separate (even when this would directly weaken their ethnic consciousness and selfsufficiency), and find and actualize new treats that can unite. Sometimes it is not even a voluntary process: the former villages have to overcome any ethnical or tribal bias in order to get help and survive in new environment. If a nation is about losing or experiences weakening of hierarchically lower ways of self-representation (ethnic and tribal), as well as successful collaboration and cohabitation despite differences, urbanization (if not in homogenous closed districts) is a fine way to reach it.

Today Dar es Salaam is the largest city in Tanzania and it has experienced a period of rapid growth after the World War II. During the rule of Julius Nyerere, Tanzania's first President, the population was pushed to live and work in rural villages in the frames of ujamaa program. However, the Tanzanians continued to arrive in Dar es Salaam longing for a more prosperous future (Sturgis 2015).

The policy of financial liberalization and decentralization carried out in post-socialist Tanzania, led to the expansion of the informal sector of economy and, in particular, to significant increase in the number of informal settlements and associations (e.g., Burbidge 2013; Lema 2013; Kinyanjui 2014). The study of social processes taking place in such settlements and societies proved to be important for understanding of the mechanisms of non-state regulation, which is especially important for the third-world countries due to the lack of state support for the poorest segments of population.

The informal links are a crucial element in the urban survival strategy in Africa (e.g., Hart, Laville, and Cattani 2010; Lindell 2010; Wilbertz 2012), Tanzanian Dar es Salaam is not an exception. It is the country's largest economic center, one of the fastest-growing metropolises in Africa, and vast majority of its residents are engaged in the informal sector of economy. Street vendors, craftsmen, garbage collectors, owners of small shops and hairdresser's - almost all of them came to the 'big city' in search of new opportunities.

In their studies social anthropologists and urbanists do not focus on informal economic relations per se, commonly they discuss the increasingly emerging informal settlements (which form the appearance of modern cities) (e.g., Augustijn-Beckers et al. 2011; Fox 2012; Desai and Loftus 2013; Chiodelli and Moroni 2014; Mahabir et al. 2016) or unregistered associations and unions of citizens aimed at mutual support in the most unforeseen circumstances (Gugerty 2007; 
Yusuf, Ijaiya G., and Ijaiya M. 2009; Adofu, Antai, and Alabi 2010; Hillenkamp, Lapeyre, and Lemaître 2013; Cling et al. 2015).

The traditional patterns of collective action worked out over the centuries, based on trust, the principle of communality and grassroots self-organization, are reproduced in the situation when the state fails to perform many social functions and delegates the concern for the population to private structures. This involves the urban planning practice and formation of public relations. Thus, in the context of the expanding urban informal sector the mutual help practices should be of particular concern and this is the main topic of the present study.

In our article we summarize the results of the field researches conducted in February 2011, September 2013 and in late September and early October 2015 in Dar es Salaam, mainly in two districts Gongo la Mboto and Mbagala (for informational purposes we also had talks with residents of Manzese, Tandale, and Mwananjamala). During the field seasons 75 formalized and non-formalized interviews with members of various mutual help groups and with people not belonging to such groups, but aware of their activities, were conducted as well as several expert interviews with lecturers from Mwalimu Nyerere Academy. During the study we also visited several meetings of different mutual help groups.

We would like to give more details on the areas where the research was carried out. In the colonial times Dar es Salaam was divided into three zones: uzunguni ( $s w$. 'the place of white people'), uhindini ( $s w$. 'the place of Indians'), and uswahilini ( $s w$. 'the place of Africans'). Uswahilini were traditionally located in areas below sea level with high risk of floods, they were considered to be unsuitable for living and therefore became a place of concentration of the poor (Moyer 2003: 207).

Today the boundaries of uswahilini are rather blurred: they can be found not only on the urban fringe, but also in the city center. This term is often used as a synonym for 'hotbed of informality' or 'slum', the latter in fact is not correct. At the same time, uswahilini host most of the informal settlements: about 80 per cent of Dar es Salaam residents live in similar conditions, not only poor people who cannot afford to settle in developed neighborhoods, but also wealthy ones (Kyessi and Sakijege 2013).

Gongo la Mboto is a Dar es Salaam uswahilini district in Ilala area, located $20 \mathrm{~km}$ from city center. Since 1982 it is a part of the city, but still looks like a village. Although Gongo la Mboto is considered as a poor area, its population is extremely heterogeneous in terms of social structure and financial status. Next to the huts built from lowquality materials you can find rich mansions with satellite dishes and 
high fences with barbed wire. In the district there are several informal settlements with borders not marked in any way: they are located in an arbitrary order. Most of the area is habitable: there are no swamps, no dumps, and no river spills.

Mbagala is located in Temeke area, it is closer to the city center than Gongo, but it is much more difficult to get there: several types of public transport are required, including 'dala-dala', a local fixed-route taxi. This is a very large and densely populated area, heterogeneous in terms of social structure. At first glance, the poor settlement planning is not so noticeable in Mbagala: there is more space between houses than in Gongo, and the area is more clearly zoned, there are rich and poor neighborhoods.

In general, Mbagala is more urbanized than Gongo la Mboto. Both districts are unofficially divided into quarters with vernacular names, which are not mapped out. Usually someone just hangs a sign board with a street name on a tree and thus the name becomes permanent.

\section{MUTUAL HELP GROUPS}

The survival strategies in African megalopolis include such traditional support schemes as mutual benefit funds, associations of people from the same area, and burial societies. Specific practices have wellestablished names: kufa na kuzikana (sw. 'death and funeral'), mchezo (sw. 'game') / upatu (sw. 'circle'), and vikoba (sw. 'pocket'). These are simple everyday mechanisms of mutual assistance in case of unforeseen circumstances: sudden illness or death, wedding, etc. The second aim of these practices is to accumulate money for various needs (such as relatively big purchases, school fees or seed money for starting a small business).

According to our field studies, most of such groups are not officially registered, but their internal structure is sufficiently formalized, for almost all the communities have a chairman, a secretary, a treasurer, and a constitution. It is worth mentioning that representatives of various strata of the population join such communities: the poor, the middle class, and even rather rich citizens of Tanzania (the only difference is the contribution amount). Mutual help groups are formed by neighbors, colleagues, and people from a certain region of the country. We also met gender-based groups - we should note a particular importance of such associations for women.

\section{Kufa na Kuzikana}

Kufa na kuzikana is the oldest type of mutual help groups in the urban environment. This refers to burial societies whose main purpose is to raise funds necessary for organizing funerals for group members or 
members of their families at the expense of voluntary contributions of the group participants. In Tanzania there is a tradition according to which person should be buried in his/her homeland, in the land of ancestors, regardless of where he/she died. Thus, there are huge expenses for body transportation, so the burial societies play an essential role.

The lecturer of Dar es Salaam University College of Education told us about the history of kufa na kuzikana:

Kufa na kuzikana was founded by people from upcountry. When they came [to Dar es Salaam] and worked for so long it happened that someone died, and usually someone from Kilimanjaro or Iringa wanted to be transported back home and it brought a lot of problems. We have to take a body home and there is no money to take the body there. And they decided to start a thing like that in order to help with transportation of the body. $<\ldots>$ Someone who came here as a simple worker and did not save some important money. He'll die and be buried here.

Along with economic functions, kufa na kuzikana communities also have social ones. Thus, in the case of funerals, apart from providing money, the community members should lend moral support to the person in whose family the misfortune has happened, i.e. they help to prepare food, to clean the house for guests, etc. In case of illness or accident the group members can bring the patient medicines, food, visit him/her in the hospital, and look after the children. In case of wedding the group participants bring food to the celebration and help with other preparations. Thus, people get socialization, social insurance, and an opportunity to know neighbors better.

Community members meet once a month; meetings take place in participants' houses by rotation, sometimes in cafes (depending on the group size). At the meetings each person should contribute a fixed amount of money: it can vary from 5 to 30 thousand shillings (US\$213) per person. The amount subsidized for funeral organization depends on who died - a member of the community or his relative.

When each particular kufa na kuzikana is formed, the group members collectively write and approve its constitution, a set of rules regulating the functions of the community, the amount of contributions, rules of conduct, possible penalties (e.g., for missing a meeting), etc.; then the chairman, the secretary and the treasurer (the funds keeper) are elected. The chairman carries out formal management, the secretary keeps records, and the treasurer controls revenues and expenses. 


\section{Mchezo/Upatu}

Mchezo/upatu is an association of people regularly contributing fixed sum to the common fund, from which each member of the community receives the gathered money in turn, to be spent on any needs. This is a classic Rotating Savings and Credit Association (ROSCA), which is organized by colleagues at work, neighbors and even children in school. The only difference between mchezo and upatu is the name: mchezo is considered an older name, created by the poor, and modern middle class people call this practice upatu. 'There is no mchezo and no upatu - just the same. Only the way you decide to call it. Big shots call it upatu, other fellows call it mchezo', one of the respondents explained.

The main goal of such mutual help groups is the financial support of their members. Usually there are 20 or more people in mchezo, they meet once a month or once a week or more often and contribute money, the amount depends on the frequency of meetings, it may vary from 1 to 20 thousand shillings (US\$0.4-8.7). The structure of mchezo is similar to kufa na kuzikana; the keeper of the mutual aid fund is called kijumbe (sw. 'messenger'); no economic education is required to receive such a position, any trusted member of the group can become a cashier.

\section{Vikoba - State-Regulated Mutual Help Group}

Another common type of mutual help group is called vikoba. The word is an abbreviation for Village Community Bank, $\mathrm{ViCoBa}$, i.e. bank for rural residents; but in Swahili it is written as vikoba, which means 'pocket', 'purse'. Vikoba provides microcredits to its members, and special consultants pro bono teach participants, how to start their own small business. The distinctive feature of vikoba is that the initiative came from the Tanzanian ruling Revolutionary Party (sw. Chama cha Mapinduzi, CCM), which adopted the program developed by Professor M. Yunus in Bangladesh in the 1970s with the aim of improving the welfare of the rural population. In 1983, M. Yunus founded the socalled Grameen Bank ('Rural Bank') in Bangladesh, aimed at financing small projects. Tanzanian authorities paid attention to this initiative, and in 2008 residents of 20 districts of continental Tanzania were involved into a program of studying entrepreneurship basics using available resources in Grameen.

The official vikoba has a single center and subdivisions at the ward level, district or street level; local groups do not have real independence. However, along with the official vikoba there are informal groups not having official registration and links with other groups and the ruling party. In this case the group is also self-sufficient and selfregulating, like kufa na kuzikana or mchezo/ upatu. 
Usually vikoba members are engaged in the cultivation, sale and resale of vegetables, fruits and beverages; they also create enterprises in the service sector. The overwhelming majority of vikoba participants are women.

At weekly meetings members of the community 'buy shares', in such a manner they collect money. The funds raised during one meeting are then used for providing one or several loans, which should be returned in 3 months with 5-10\% interest. The approval of each loan is taken to a collective discussion with subsequent voting. At each meeting all collected funds are distributed, except the interest and fines, which form the treasury of vikoba. The possible size of the 'grant' for each member depends on the amount of money contributed to the common fund. Many participants leave vikoba during the first year, because they do not have an opportunity to attend weekly meetings or pay fines for absence. At the end of the year the group decides whether to start the second-year cycle or cease to exist. The secondyear cycle is considered more successful: community members already know each other and how to do business. Official vikoba groups have accounts in banks, it is prohibited to participate in two or more cells of vikoba at once.

The structure of vikoba is the same as in kufa na kuzikana or upatu groups. However, membership is limited to 30 participants; if this number is exceeded, a new group is created. Many respondents agreed that 30 is the maximum number of people for being controlled easily. Each new member needs a guarantee from the one who brought him/her to the group. In case of default on a loan the responsible person pays for the offender.

\section{ETHNIC/REGIONAL COMMUNITIES}

Sometimes mutual help groups are formed on ethnic or regional principle: apart from the basic functions of economic insurance and social support they are aimed at preserving the traditional culture of a particular ethnic group in the polyethnic megacity. Of course, such communities follow the trend of preserving the differences rather than 'melt' them in a big city and thus contribute less to the nation-building process, but we must shortly describe them for the purpose of full coverage.

During our study we met eight such communities; Tanzanians call them 'tribal groups'. When a new member is admitted to such community, participants check whether the person really belongs to the ethnic group: they ask about the village of origin, street where his/her relatives live or lived, and then check this information through friends who live in that village. Potential members are asked about the ethnic language (even people born in Dar es Salaam usually know a few 
words in their ethnic language), pay attention to appearance, pronunciation, and to the clan name, which also reflects ethnicity. Respondents emphasized that trust is based on a common culture and common blood, this is considered of much greater value than the possibility of appealing to state institutions in case of troubles.

Sukuma respondent said,

I'm a member of kufa na kuzikana. Kufa na kuzikana is like a group which contains the people who have... who share the blood or who are lucky people which have one clan, the people who are sharing blood. $<\ldots>$ We have some qualifications which we can make sure to understand you are Sukuma or not. Come with your birth certificate and we can know [where you were born]. And we'll ask your name, your local name. Here we use local names of Sukuma. So, what's your name? Your local name? And we can tell you are Sukuma or not Sukuma. <...> If you want to join our group you must get more than 10 people from the group who understand you. Who know you. This ten people can support you to make sure you can be a member of our group.

Nyamwezi respondent told,

The main condition is to be Nyamwezi but we'll have to confirm if you're really Nyamwezi by asking your homeland history and we have members from different districts of Tabora [Nyamwezi region]. Apart from asking to speak Nyamwezi, we can alternatively ask him/her to talk about some Nyamwezi culture like Nyamwezi customs and rituals practiced by Nyamwezi people. $<$...> We can ask a person to name about three to four of our traditional dances.

\section{BASIS OF TRUST: MECHANISM OF CHOOSING GROUP MEMBERS AND THE PROBLEM OF STEALING}

In our opinion, the most important informal foundation of trust within the mutual help groups is the mechanism of choosing its members: if a community is going to accept a new person, one of the acting members must vouch for this person. Most often several people decide to create a group, focusing on their previous experience, that is on the groups in which they participated living in another district or city. After that each of them brings his friends, and those - bring their friends, i.e. very often the group is initially formed between friends.

Gongo la Mboto citizen said: 'You can't come without connection. They can't agree with you, they won't trust you, because no one guarantees you. In mchezo all the people are friends because they believe dog walks with dog. Cow walks with cow! It is impossible for lion to walk with goat, very difficult'. 
When a new member comes to the community, a group discussion of the acceptance of the proposed candidature is arranged. If one of the members says that the candidate should not be trusted, the chances of getting into the community are rapidly declining. The final decision is made by a vote. Moreover, the group conducts an informal 'investigation': a potential member is being tracked: his neighbors, colleagues and relatives are being asked questions about him and his behavior. The community is trying to find out about the person's sources of income and their stability. It is important, that group members' choosing mechanism has nothing to do with the provenance of person, region of origin or tribe (except for regional/ethnic communities described above), these new social bonds are formed only on the basis of reliability and profile in the community. In some sense this means the rewriting of social bonds from the level of traditions and given environment to the level of personal achievement and chosen environment; openness to the acceptance of new members irrespective of tribe helps to strengthen nation-oriented liaisons.

Now there is a tendency to take someone into the community on a temporary basis for a month or three, during which the group will also observe the person to make a final decision. A girl from Gongo la Mboto said:

When they invite me, they are looking at me for three months, my habits, my behavior, they ask other members: how do you see this person? So not everybody [joins the group], because some people they are very harsh! If you tell them this month it is already $25^{\text {th }}$ you have to give money to vikoba, they start: 'Hey, do you know my problems?' < ...> They are watching how do you live, how do you talk, how do you communicate with people.

She added,

They ask you to join, but they will be watching you secretly for three months. They watch how you are living around there, they will see how you are going for lunch, breakfast, they are going to watch you, how do you eat. Do you spend too much money [on lunch, dinner]? They treat you normally, but they are watching you.

Nevertheless, even in the case of a unanimous decision for acceptance, the person, who initially invited this new member, remains responsible for him, sometimes even financially (the relevant documents might be signed). In the already mentioned kufa na kuzikana of the Sukuma people in order to join the group a guarantee of ten active members is required, and subsequently they are financially responsi- 
ble for the newcomer. According to our respondent, in this group there was a case, when a person lent money and fled. At the time of the interview ten people, who vouched for him, still paid the stolen amount without any objections. In many groups a necessary condition for choosing one of the leaders (chairman, secretary, treasurer, i.e. individuals, who have access to a common fund) is that they have their own house in the area. This is explained by the fact that 'It is so hard to run with your house, and it's impossible to leave your own house', because no community has so much money for such a step to be justified. Thus, the respondent summarized,

- But, what if somebody tends to run away with money?

- Now running away to where? Because as a member, you've constructed the house here, you've the property which we know, you can't even sell your property without the information circulating to other people that you're selling your house. So, it's not easy to run away. <...> But in terms of somebody defaulting to pay and run away isn't easy because we're the established individuals, with families, so you can't run from your family for one million.

- If you run away with your family?

- You can't run away, you have children here and they're schooling... life is continuing. Like the way you see who assisted here... he owns a garage, he's having a fishpond, we enjoy some fish... Do you think he can run away?! Not easy.

The most important informal basis of trust between neighbors and colleagues is the duration of acquaintance. Informants said that it is necessary to know a person for at least a year to draw any conclusions about his reliability. An important condition is also reputation and public opinion. According to our observations, the 'word of mouth' in Dar es Salaam is still the main channel for information dissemination, not only in the poor, but also in more affluent areas. Therefore, if a person is involved in some dubious business, very soon everyone will know this. It becomes possible to join various mutual help groups only thanks to a good reputation among neighbors and friendly relations with people around.

- Well, that's why we said we also look at the social status... If I have taken a loan of one million and I am going to run away. They are going to say no, please, can we have your car [if you are not able to return the money], can we have your... And you can't reach to that extent because you also need to maintain your social status. In the community you're somebody, you need to maintain respect. 
- So, you mean that, if you do something wrong maybe inside the group, may be the next day the whole area will know!

- Yes, all area will know.

- And your reputation will be gone?

- Yes, reputation will completely be downgraded. And everybody will say: Oh, that's the man who stole the money of the group.

According to our respondents, in order to trust a person it is necessary to know, where he or she lives, and even better to be familiar with the person's family.

One of the informants said:

Even if she is an employee [of the college], you must know him or her, where is he living? I know Don is living at Mzizini, I know his family, so he is my friend, I can guarantee him. That is not from nowhere.

Another respondent noticed:

- What makes you trust your money to these people?

- I know them, I know where they live... we're friends. The factor of behavior wise, I know most of them. Both behavior can change but at least you know where they are, you know their children. So, at least that is the mutual relationship we have and makes us trust each other.

According to the general opinion, cases of thefts of the common fund most often happen in mchezo groups.

Dar es Salaam resident said

Mchezo is like a lottery. Sometimes the group can be collecting money and give to each other in a cycle without any problems but sometimes, you may welcome other members in a group... then money collection among other members starts to be a problem and sometimes, others can even run away with group money and this is very common for mchezo. So, in mchezo is like lottery, you can't rely much on it.

A street vendor said:

- When you put money there [in the group], you do not get any documents to prove that you kept your money there, it's just a trust thing, and that's also what I find difficult, because the other group you find people, who were saving those money they have disappeared! No way to trace those people, so your money will be like pshhhh! Gone!

- What makes people trust those groups? 
- People are desperate, people, especially women... Well, most of us, we do not know how to save money, and also we believe in loans, we believe in loan more than in saving your own money, your own stuff. That's all about that, that is why people trust.

\section{OFFICIAL REGISTRATION OF MUTUAL HELP GROUPS}

Many informants expressed doubts about the necessity to interact with the state and its institutions (including the police) in terms of official registration of mutual help groups, gaining the group's documents legal force and resolving conflict situations. Most respondents said, that their group does not actually need registration, since it does not bring any benefits (for the group is still formed on the base of trust), while registered groups have to pay taxes. Moreover, the registration process is incomprehensible, takes a lot of time, and complicated by numerous bureaucratic barriers.

'Because we believe we do not need it... So we want to be on our own. $<\ldots>$ The issue of registration, some do not know where to start from, and of course there are some fee have to pay... People do not want to waste money', - lecturer from Mwalimu Nyerere Memorial Academy said, who is a treasurer in her vikoba group; 'The question is that registration involves some processes, complicated processes. So most people find, why do we need to waste time... why do we need to waste our money? $<\ldots>$ So, it means the system of registration is still cumbersome for most people and therefore we decide to avoid it. $<\ldots>$ When the group is registered, it has to pay taxes', - lecturer from the same Academy emphasized; 'You can come for somebody's signature and they say: ooooh, boss if far from Tanzania, he is in Kenya for 2 years. You may wait for a single signature for 2 years!!! Our government are so crazy!' - a former member of mchezo group noted.

When we asked a girl, the member of two mutual help groups, about registration, she said: 'To be honest, we'd no idea about it'. Some groups even started the registration process, but it was not completed because of various complexities. A man, kufa na kuzikana member said: 'For you to register something it can take a lot of money, corruption. When we started registering our organization times were with a lot of money with a lot of disturbance. It was more than two years! Very-very bad government!'

Most Dar es Salaam citizens, especially low-income ones, treat taxes as a waste of money, there are two most bright statements from respondent-lecturer on the issue: 'People are running away from the government because the government seems like an enemy of the peo- 
ple through taxation', 'Some Sukuma people have their famous saying that, it's better to take money and bribe the woman than paying tax to the government'.

The situation is somewhat different in vikoba groups, where members tend to have jobs and stable earnings. There is one more type of group for people with stable earnings - SaCCOs (Savings and Credit Cooperative Organizations). Usually people, who work in one place, unite in SaCCOs, but it is considered expensive. More affluent vikoba members see point in registration: it ensures the official recognition of the group by the state, which allows receiving contributions from government; moreover, if registered group has a bank account, it can get a loan on preferential terms (this advantage is not claimed by members of groups from poor areas, since the bank requires that the borrower has a collateral as a guarantee).

We can get a loan from the bank, because we are registered',a member of kufa na kuzikana said. 'To be legally recognized is better than being not, because sometimes there's money coming from the district level to give to women or youth groups. So, if you're registered you can easily receive the contribution', - said female Academy lecturer. 'Nowadays, many such groups they have get registered because if they are the ones to apply loans or grant from their government it would be easier because they are known by government. If you have not registered your group you will play in risky side. Yeah for now people are saying that it is very important because they want to play in safe side. But if you are registered by the government it will be easier to help you (Gongo la Mboto citizen said).

On the other hand, many perceive this opportunity of getting contribution from the state as government pressure and an attempt of control; some say that politicians make contributions to groups just in the period of their campaigns, because it is much easier for them to use people organized into groups than if they were scattered. Many respondents emphasized that it is important for their group to remain unrecognized, so that the state would not know about them and could not control them.

\section{GROUP LEADERS AND RELATIONS WITH POLICE}

Most respondents note that registering the group is useless for resolving conflict situations, since the police are extremely corrupted so that appealing to its officers will lead only to unnecessary waste of money. 'They [unscrupulous members of the group] may bribe the police and the police may not come. They may not take the issue serious because of the bribe ... Even if you get registration, registration does not mean 
you may not bribe the police... Bribe and corruption is everywhere', said lecturer from the Academy; 'When you go to police, they need money to make the follow up for your money. So, you continue losing more money. So, it's like... well, presence and absence of [legal] system might be meaning the same thing', 'Probably he has run away with 50 thousand shillings, and the police says, "Give us 10 thousand shillings for fuel", and they'll go to take that person. After two days they call you again and say: "You know, we want also another 10 thousand shillings, we want this person to send to the court". From there, they're going to disturb you, so, you find that you're using 100 thousand shillings to find 50 thousand shillings!' - he continued. 'You can't trust the police, you can't trust the judge, and you can't trust everybody. As long as you got money - everything is simple, you can cheat the law, you can do anything! You can buy them all' street vendor said.

Respondents told about their personal experience of bribing the police, stressing that this is a very common everyday practice; they called definite 'amounts' in one case or another. They said that a bribe to the police can be given even via 'telephone money' (in Tanzania there is a popular practice of rapid money transfers from one phone number to another).

Quite a few respondents in their interviews spoke neutrally about the police, saying that in case of theft in mutual help group it is possible to appeal to them, but they could not describe the process and the result. Only one respondent said that the police were helpful and caught the runaway.

Thus, most members of mutual help groups find the appeal to police a meaningless action, even explicitly prohibited by their constitution. A man from kufa na kuzikana said, 'According to our constitution you are not allowed to go to the police for something which is in the book [information written down by the secretary of the group: who took, which amount of money, etc.] any problem - just come, we discuss. The 10 people [responsible for member, who failed to return the loan] will pay according to our constitution'.

Most often in a conflict situation group members appeal to their leader and conduct collective discussion of the situation. A male lecturer noticed, 'Police usually is the last option but the first option is how you can use diplomatic and social means to recover back your money'. Here is a specific scenario of the conflict situation, presented in an interview with the female vikoba treasurer, lecturer of the Mwalimu Nyerere Memorial Academy (an identical scenario is presented in an interview with an accountant girl from college in Gongo la Mboto):

- In case you fail to pay, group members can go and take your TV. 
- What happens is you refuse and close the door?

- Yah, that happens because we can't tell the police straight away...

- Will the police let them take TV?

- The police at that time aren't there. They are [group members] just based on their own, they just inform local leaders, and then they come and take the TV and if you repay the amount, they will return your TV'.

Most respondents regard group leaders as a highly respected force, which should be relied as distinct from the state institutions and the corrupt police. An Academy lecturer told,

But it's [mutual help group system] something which is based on social authority. And it also enables us to elect the leadership which's very strong. The head of the vikoba is the Headmaster of secondary school. Another head of the vikoba is a soldier. So you can see... these are people who have social image, kind of social authority is so high.

\section{GENDER ASPECT}

When we talk about the gender aspect and women's mutual help groups, it should be taken into account that the key moment in their development was the change of rural way of life to urban with preservation of traditional family values and cultural mindsets. As a rule, in Tanzania women did not work and at the same time were fully responsible for housekeeping and child-rearing. Thus, they used to spend most of the time at home. Tanzanian women practically did not take part in labor relations, they did not have the opportunity to receive education and earn money. In the 1970s, a campaign for women's rights started, which led to changes in the economy among other things.

In addition to access to education and work women wanted to be more independent from men and to have an opportunity to raise their social status not through marriage, but by their own efforts, which was not possible in traditional culture. Although, to date the situation with women's access to education has changed significantly, many families still adhere to patriarchal attitudes, trying to educate their eldest son (sons, if available) and expecting that daughters should marry and do the housework. That is why the main opportunity to get work, especially for married women with children, is the start of their own small business. In this case we mean small business like cultivation and sale of vegetables and fruit, poultry, sale of beverages or cooked food, secondhand clothes, work in the service sector (most often in hairdressers).

Obviously, in addition to some knowledge you need an initial capital for starting your own business. Most women from the poorer quar- 
ters of Dar es Salaam do not have the opportunity to appeal to a bank. There are several reasons: the absence of officially registered property (house, car), which could be used as collateral; financial illiteracy; lack of experience of interaction with official structures; high interest rates in banks. That is why mutual help groups, which provide loans without paperwork and owning expensive property, are very much appreciated by women, who decided to start their own business.

A young man who lives in uswahilini and does not have a permanent job, told us about the reasons of popularity of mutual help groups among women,

When we talk about vikoba, we mean business like small enterprises with humble income... Many women are engaged in small business, and vikoba gives them an opportunity to raise capital, for the interest rate is very small there! Vikoba or kufa na kuzikana helped them a lot, especially in big cities.

'It [vikoba] has helped many people, maybe for personal expenses, maintenance of house, you easily get a loan and not everybody can afford to get a loan from the bank... the interest is very high and collateral may be needed', Mwalimu Nyerere Academy female lecturer said. She stressed that even if a person owns a house, but there are no formal documents confirming it, the bank still will not give a loan.

One of our informants, selling fruit in Gongo la Mboto, admitted that she was afraid to deal with the bank: in case of default of interest collectors could come and seize her house, and nothing could be done with it. In mutual help groups, founded by friends and neighbors, such issues are resolved on good terms.

A woman from Nyamwezi tribal group in Gongo la Mboto, engaged in her own business, said:

If an ordinary member does not bring contribution, we take her household items used as collateral so as to compensate the loss, and it does not matter if the items belong to you or to your husband... We'll take them even if they belong to your husband because we do not know, maybe you spent the group money with your husband!

Besides the possibility of obtaining a loan on preferential terms, participation in mutual help groups for women is considered as an opportunity to increase self-awareness and social significance. According to many respondents, in a traditional society women felt 'left behind'. Therefore, apart from improving welfare, women consider participation in such groups as an additional opportunity to get out of the house and chat with friends. 


\section{Women from vikoba said}

Women feel they are left behind. And need to come together and assist each other. And another thing is that men are going out to have a drink or two and women are left at home. So when it comes to kitchen parties [organized by vikoba], they are happy, they dress well, dance a lot and at least have a reason to go out.

Our respondents also mentioned that mutual help practices are more popular among women than among men due to psychological reasons: women naturally tend to cooperate; they are more responsible and not aggressive. Women always help each other and rely on each other in running the household without any groups: bring products from the store, look after the children, etc. A female lecturer from Mwalimu Nyerere Academy said: 'If a woman says she takes loan for school fees - she takes it for school fees. But when man says for school fees - it may be for some drinks... women can manage the funds. They feel responsibility'.

A street vendor said:

Women trust each other, not like men, women have this traditional norm, this thing. Nowadays people have to empower themselves, women want to empower themselves, they do not want to depend on men any more. So how do they do that? This is the only way. I think that's why [mutual help groups are popular among women].

A girl working in a college in Gongo la Mboto, being a member of vikoba for women, told us 'Men in the college do not have such organization because of a conflict of interest. We contribute money for all of us, for others, somebody may use your money for her advantage, and men can't reach agreement. Men can't realize why somebody benefits from their money'.

A lecturer from Mwalimu Nyerere Academy shared his opinion on how women's mutual help groups have evolved:

Usually these informal organizations used to be like talking shops for women, to discuss men. But this time things have changed. People are more interested in 'how can I get a loan to produce and improve my livelihood', 'I would like to have more family goods like cooking-pots' - these are the issues. $<\ldots>$ And women do not have a serious work at home. Usually. But this time due to the complexity in economics changes in the social system informal organizations are living and taking a very good place. 
We interviewed many women who moved to the city recently and went through crisis due to separation from their family and home town/village, where they could always rely on the help of their relatives. This is also one of the reasons why there is a need to create a support group to compensate the lack of ties with fellow countrymen. It is interesting that many people, even if they can apply for financial support to their relatives, still prefer to appeal to groups, because their members, unlike relatives, initially commit themselves to help each other.

\section{URBAN LIFE AND RURAL MENTALITY}

Obviously, the above-described features of mutual help communities, including people's ability to organize themselves, trust without legal obligations and settle conflicts without police intervention did not appear accidental, especially in the urban space which is less favorable for these practices. Such habits were brought from their native villages, where the features of rural mentality, the custom to rely on relatives and neighbors and to solve problems together are natural (e.g., Bondarenko 2014). A female lecturer said

In the village it's different. In village people help each other as responsibility because, if a person dies, some people will bring firewood, other bunch of bananas, others with milk, other with nothing but to offer physical help, for instance some cleaning. It's like an obligation, but in town no one is obligated to give a hand. If you're here and people nearby aren't your relatives, they just stay at home and no one will be obligated to give you a hand. So, in towns people in order to get help - they need to be in groups, because nobody is obliged to do so. But in villages you live with your relatives. Either your uncles, your aunts, everybody who's around you is your relative and they are obliged to help you.

Some respondents admitted that such practice comes from the village. A Gongo la Mboto citizen believes '[When people come to the city] they try to live like in a village'. Other lecturer emphasized 'We're trying to live the urban life in the rural thinking. So, what we're forging here is basically the rural settings. Because in the villages we have these kinds of associations. So, when you come to town, we're living the urban life with the same village social thinking. So, what we've transformed is basically the place of residents, but the mind is still rural'.

Traditions of mutual aid, community life, 'communalism', as one of our respondents said, have both positive and negative sides. Tanzanians call the tradition of joint activities and openness a distinctive feature of their mentality (important nation-level trait). We have two inter- 
esting statements about this (it is noteworthy that respondents belong to completely different social strata: the first fragment is from the speech of the Academy teacher, the second one from street vendor).

People still think they have to forge some social lifestyle and they do not want to live individual lifestyle. We still wish to live communal lifestyle... So, that's the reason why you find that in Africa we sleep under the same blanket, you can't talk of an individual blanket. When you've got a job, that's not your job, it's the job for the family. You're married to the family not married to your husband... you're married to the family. Every person feels like you're responsible for him or for her in the family; ever since you're married in that family. So, that's the communal thinking. So, the history of these associations takes roots from African social life... our grandparents needed each other because no one was self-sufficient to ensure that he'd produce which's enough to guarantee the survival (interview with Academy lecturer).

We are more like social people, we are in the socialization, we are more like to share stuff, that's how it is, that's why it's easy to find a friend in Tanzania! Not like in Kenya or somewhere else. Nobody minds, you can come to anybody's house and ask for a cup of water, and without any invitation you'll find it. You may be hungry, so you just knock on door, people look at you and you go: 'I haven't eaten for 2 days...' And they go: 'Mama! Or, Amina! Give this guy a plate of ugali [national dish made of maize flour] or something'. You know, we are like that! (interview with street vendor).

On the one hand, such attitude helps people to achieve more together, gives guarantees of survival and promotes socialization. On the other hand, it is some form of mutual control, when your whole life passes in the sight of neighbors and heavily depends on their opinion. 'One thing about Tanzanians: they like gossip and rumors and following up on each other's life', mchezo member from a rather wealthy district said. In many interviews respondents noted that group members know where you live, 'which door to knock', where you work, where your children are studying and so on. The reverse side of system built not on legal reasons, but on trust, is the application of non-legal sanctions in case of undermining the trust and practice of 'family hostages'.

In most Tanzanian families the family would take the blame for one of the members fault, it's normal and I've seen it in most cases. Mostly the mothers are the first to carry the 
burden. And yes, there is something about honor and disgrace to the family. Your family might also tend not to deal with you no more, they will unattach themselves from you. You ruined the family's respect to the surrounding society. Sometimes the family takes the blame and they pay up their relative's mistakes to at least maintain the little honor left (interview with a mchezo member).

- What would you do if you find out the person has lied?

- No official punishment but they'll be against you and they will blame you for lying. In some cases, all family members have to become guarantors of their relative's participation in a group (from an interview with a girl, who is a member of two mutual help groups).

Aa an Academy lecturer generalized:

It is [respect in the community] very important. While you're taking liberalism and capitalism, for us here, we're taking typically like communalism... communism.... That's the matter of social satisfaction, that's kind of life we're used to, kind of communal life style. And there's no life outside the social groups.

At the same time, according to some respondents, the desire to help each other and build good neighborly relations, the collective responsibility of family members before the community, which are traditional for Tanzania, come into some contradictions with Western values, that are actively broadcasted in the urban environment through the media, the Internet, etc. Some informants see this as a threat to the preservation of good and peaceful relationships in the heterogeneous community of the inhabitants of Dar es Salaam and Tanzania in general, while others are convinced, that traditional values are so deeply rooted in the minds of people, that they cannot be superseded.

Now, the market has entered in the African continent at the disadvantaged position. It has come as a colonialism, has come as exploitative mean to the people. So, people will tend now to run away from the market and get back to the community as savior, to village life. So, we're not interested more in the market but we're interested in community life. $<\ldots>$ So, we think market is our enemy and the best friend is a community (from interview with an Academy lecturer).

\section{TRANSFORMATION OF MUTUAL HELP GROUPS}

As it was already mentioned in our previous study (Ivanchenko, Zelenova, and Popov 2015; Ivanchenko and Banshchikova 2017), rapid 
transformation is still one of the key characteristics of mutual help communities among Dar es Salaam citizens. While in 2011 respondents told about different types of groups with different separate functions, in 2015 we found out that the groups' functions became similar: kufa na kuzikana, mchezo and upatu started giving their members loans with a small interest, as is it done in vikoba communities; in all the groups there can be a practice of straight donations to group's members in case of funerals, as it is done in kufa na kuzikana. It is interesting to note, that in Gongo la Mboto, less urbanized neighborhood, these processes are generally less visible and they are taking place slower, that in Mbagala, a bit more urbanized and civilized city space: in the former people usually refer to the groups exactly as $k u f a$ na kuzikana, mchezo/upatu, vikoba, while in the latter, where all groups tend to carry out similar functions, citizens usually say just 'the group from such-and-such street' or 'the group of such-and-such people or region of provenance'.

Furthermore, those communities, where members have more or less stable earnings, gradually try to pass the registration procedure in order to gain recognition and the opportunity to solve group's problems by legal means. At the same time, the groups created by poorer citizens or those, who do not know, how the legal system should operate in the country due to low education level, stay in unregistered communities, even knowing the risks and probably already having a negative experience. Thus, stratification is gradually taking place among people involved in mutual help practices: part of communities follow the government's claims to get registration and enjoy the benefits of state guarantees and support, while for the poorer communities nothing changes. In this case there is only a further preservation of village values in inappropriate metropolis space.

It is important to note that this situation has emerged not only due to the poverty of groups' participants, but also due to the spread of corruption among the officials and police. Thus, for uswahilini citizens informal bases of trust are what they could rely on in the village, what their ancestors relied on, and it turns out that in a big city people do not have motivation to change anything, not only because of the established set of traditions and mentality, but also because of external circumstances.

\section{CONCLUDING REMARKS}

Therefore, we can observe very conditional case of urbanization, when people move to the city only physically, while most uswahilini citizens stay in the world of their village. This is the evidence of persistence of traditional values in Tanzania as well as lack of state support for the 
poorest citizens. These people do not have any impetus for transition from the informal foundations of trust to formal ones, until the benefits of state (social support, persecution for fraud) overbalance its disadvantages (corruption). Thus, the Tanzanian example shows the concrete results of artificial, yet successful state-building: the process that unfolded too fast in the historical perspective, changed the form of government and brought many new features to the society, but it turns out that for vast majority of poorest population these features seem to be either unaffordable or useless. In many senses they are invisible to state - exactly as the state is invisible for them (putting aside peaceful life without military conflicts or civil wars, people would not take it into account unless they face such events). So, real success in state-building should appeal to the poor, because they are the last to benefit from it and yet they are sustainable part of the population, even the majority. Improving life and living standards of the majority of population is a hard tack for any government, and anyway it is a very slow process.

Paradoxically, strong pre-state traditions of community life and self-organization, characteristic of rural Tanzania, nowadays help urban Tanzania to grow up, and therefore pre-state traditions become the tool of state-development under peaceful circumstances. It is noteworthy, that ethnic/regional communities constitute the minority of mutual help groups. In the majority of groups supra-ethnic component dominates: after moving to a big city, colleagues at work and new neighbors of various ethnic identity and from different regions form new ethnicity-indifferent social bonds. Our respondents confirm these assumptions, speaking about inter-ethnical relations:

In the city it is impossible to live separately, you cannot say: 'You're not from my tribe, I will not talk to you' - it's silly. There are many people here and everyone should live together and help each other ... All the tribes come to the city, tribes from everywhere, all of them mix, get married, live and work together. We greet each other, we are friends. I have friends from all tribes: Chagga, Nyakyusa, and Digo all of them. We all live together.

This weakens the features that separate while strengthens the features that unite, and therefore contributes to Tanzanians' common supra-ethnic national identity. It is clear, that under peaceful circumstances urbanization and mutual help practices play the role in nationbuilding process: people move from village to city and from traditional social bonds to chosen social bonds - they rewrite social landscape according to new rules, but with 'old' power, coming from traditions of mutual help and communality. Thus, pre-state features help to strengthen successful nation-state in Tanzania's case. 


\section{ACKNOWLEDGEMENTS}

The paper is an output of the 2018 Basic Research Program at the National Research University Higher School of Economics.

\section{REFERENCES}

Adofu, I., Antai, E., and Alabi, O. 2010. The Informal Financial Markets Operates Mostly on the Principles of Rotating Saving and Credit Associations (ROSCA). Continental Journal of Social Sciences 3: 7-17.

Augustijn-Beckers, E., Flacke, J., and Retsios, B. 2011. Simulating Informal Settlement Growth in Dar es Salaam, Tanzania: An Agent-Based Housing Model. Computers, Environment and Urban Systems 35: 93-103.

Bondarenko, D. M. 2008. Education and Tolerance in Contemporary Tanzania: The Ethno-racial and Religious Aspects. In Korotayev, A., and Demintseva, E. (eds.), Interracial and Interethnic Relations in Contemporary Tanzania. Publications of the Russian Complex Expedition to the United Republic of Tanzania (2005 Field Season) (pp. 94-121). Moscow: LENAND. Original in Russian (Бондаренко Д. М. Образование и толерантность в современной Танзании: этнорасовый и конфессиональный аспекты // Межрасовые и межэтнические отнотения в современной Танзании. Труды Российской комплексной экспедииии в Объединенной Республике Танзания (сезон 2005 г.) / Ред. Коротаев, А. В., Деминцева, Е. Б., с. 94-121. М.: ЛЕНАНД).

Bondarenko, D. M. 2014. Communality: A Foundation of Sub-Saharan African Historical, Cultural, and Socio-political Tradition. Vostok / Oriens 2: 10-22. Original in Russian (Бондаренко Д. М. Общинность: первооснова историко-культурной и социально-политической традиции субсахарской Африки // Восток 2: 10-22).

Bondarenko, D. M. 2016. The Postcolonial World: Nation-Building and the Historical Past. In Tishkov, V., Filippova, E. (eds.), Contemporary Nations' Cultural Complexity (pp. 224-240). Moscow: Politicheskaja entsiklopedija. Original in Russian (Бондаренко Д. М. Постколониальный мир: формирование наций и историческое прошлое // Культурная сложность современных наций / Отв. ред. Тишков, В. А., Филиппова, Е. И., с. 224240. М.: Политическая энциклопедия).

Burbidge, D. 2013. Trust Creation in the Informal Economy: The Case of Plastic Bag Sellers of Mwanza, Tanzania. African Sociological Review 17 (1): 79-103.

Chiodelli, F., and Moroni, S. 2014. The Complex Nexus Between Informality and the Law: Reconsidering Unauthorised Settlements in Light of the Concept of Nomotropism. Geoforum 51: 161-168.

Cling, J. P., Lagrée, S., Razafindrakoto, M., and Roubaud, F. (eds.) 2015. The Informal Economy in Developing Countries. Oxon: Routledge.

Desai, V., and Loftus, A. 2013. Speculating on Slums: Infrastructural Fixes in Informal Housing in the Global South. Antipode 45: 789-808. 
Fox, S. 2012. Urbanization as a Global Historical Process: Theory and Evidence from Sub-Saharan Africa. Population and Development Review 38: 285-310.

Gugerty, M. K. 2007. You Can't Save Alone: Commitment in Rotating and Savings Associations in Kenya. Economic Development and Cultural Change 55 (2): 251-282.

Hart, K., Laville, J., and Cattani, A. D. (eds.) 2010. The Human Economy: A Citizen's guide. Cambridge: Polity Press.

Hillenkamp, I., Lapeyre, F., and Lemaître, A. (eds.) 2013. Securing Livelihoods: Informal Economy Practices and Institutions. Oxford: Oxford University Press.

Ivanchenko, O. V. 2013. Tanzania: Relations between the National and the Ethnic Elements in Self-Identity of Large Cities' Inhabitants. Asia and Africa Today 6: 53-59. Original in Russian (Иванченко О. В. Танзания: самосознание национальное и этническое. Азия и Африка сегодня 6: 53-59).

Ivanchenko, O. V., Zelenova, D. A., and Popov, P. A. 2015. Tanzania. Mutual Help in Urban Communities. Asia and Africa today 4: 35-40. Original in Russian (Иванченко О. В., Зеленова Д. А., Попов П. А. Танзания. Взаимопомощь в городских сообществах. Азия и Африка сегодня 4: 35-40).

Ivanchenko, O. V., Banshchikova, A. A. 2017. A Substitute for the Government: Alternative Social Practices in Mutual Help Groups in Modern Dar es Salam. Conflict Studies / nota bene 4: 47-55. Original in Russian (Иванченко О. В., Банщикова А. А. Заменяя государство: альтернативные социальные практики в группах взаимопомощи в современно Дар-эс-Саламе. Конфликтология / nota bene 4: 47-55. DOI: 10.7256/ 2454-0617.2017.4.24637).

Kinyanjui, M. 2014. Women and Informal Economy in Urban Africa. London: Zed books.

Kyessi, A., and Sakijege, T. 2013. Formalizing Property Rights in Informal Settlements and Its Implications on Poverty Reduction: The Case of Dar es Salaam, Tanzania. Proceedings of the Annual World Bank Conference on Land and Poverty. The World Bank, Washington DC, 8-11 April 2013.

Lema, N. C. 2013. Assessment on the Informal Sector and its Impact to the Economy in Tanzania: The Case of Arusha Municipality. International Journal of Research in Social Sciences 3 (2): 184-198.

Lindell, I. (ed.) 2010. Africa's Informal Workers. Collective Agency, Alliances and Transnational Organizing in Urban Africa. London: Zed books.

Mahabir, R., Crooks, A., Croitoru, A., and Agouris, P. 2016. The Study of Slums as Social and Physical Constructs: Challenges and Emerging Research Opportunities. Regional Studies, Regional Science 3 (1): 737-757.

Moyer, E. 2003. In the Shadow of the Sheraton: Imagining Localities in Global Spaces in Dar es Salaam, Tanzania. PhD thesis, Faculty of Social 
and Behavioural Sciences (FMG), Amsterdam Institute for Social Science Research (AISSR): 207. Award date: 14 November 2003.

Sturgis, S. 2015. The Bright Future of Dar es Salaam, an Unlikely African Megacity. URL: https://www.citylab.com/design/2015/02/the-brightfuture-of-dar-es-salaam-an-unlikely-african-megacity/385801/.

Wilbertz, C. 2012. The Informalization of the Private Sector in Sub-Saharan Africa and its Impact on Poverty Reduction. Copenhagen: Copenhagen Business School. URL: https://www.academia.edu/19601129/The_infor malization_of_the_private_sector_in_Sub-Saharan_Africa_and_its_impa ct_on_poverty_reduction?auto=download.

Yusuf, N., Ijaiya, G. T., and Ijaiya, M. A. 2009. Informal Financial Institutions and Poverty Reduction in the Informal Sector of Offa Town, Kwara State: A Case Study of Rotating Savings and Credit Associations (ROSCAs). Journal of Social Sciences 21 (3): 231-234. 